\title{
GREEN CONCEPTS AND MATERIAL FLOW COST ACCOUNTING APPLICATION FOR COMPANY SUSTAINABILITY
}

\author{
Rochman Marota*1 \\ *) Faculty of Economic, Pakuan University \\ Pakuan Road, PO Box 452, Bogor 16143
}

\begin{abstract}
Health equipment and furniture become a complementary factor for good health services to the communities. Management of health equipment and furniture is started by manufacturers within the industry scope and sustainable business processes. This study aimed to apply green concepts and MFCA at PT XYZ, and to analyze their effects on the dimensions of the company sustainability. To measure the effects of green concepts and MFCA on the dimensions of corporate sustainability, a multiple regression analysis was used. The analysis showed that they gave significant effects from the results of the F test, $t$ test and probability test. From these results, a number of suggestions for improvement of production process performance as managerial implications for maintaining the stability of the company sustainability index were formulated.
\end{abstract}

Keywords: efficiency and effectiveness of production cost, green concepts, the company sustainability, material flow cost accounting

\begin{abstract}
ABSTRAK
Alat dan furnitur kesehatan menjadi faktor pelengkap penyelenggaraan pelayanan kesehatan yang baik kepada masyarakat. Pengelolaan alat dan furnitur kesehatan dimulai oleh produsen dalam lingkup industri dan proses bisnis yang berkelanjutan. Penelitian ini bertujuan menerapkan green concepts dan MFCA untuk PT XYZ, menganalisis pengaruh keduanya terhadap dimensidimensi keberlanjutan perusahaan. Untuk mengukur pengaruh green concepts dan MFCA terhadap dimensi keberlanjutan perusahaan digunakan analisis regresi berganda. Hasil analisis menunjukkan bahwa Green Concepts dan MFCA memberikan pengaruh signifikan dari hasil uji F, uji t dan uji probabilitas. Dari hasil ini dirumuskan saran perbaikan kinerja proses produksi sebagai implikasi manajerial untuk menjaga stabilitas indeks keberlanjutan perusahaan.
\end{abstract}

Kata kunci: efisiensi dan efektivitas biaya produksi, green concepts, keberlanjutan perusahaan, material flow cost accounting

${ }^{1}$ Corresponding author:

Email: rochmanmarota@yahoo.com

\section{INTRODUCTION}

In the concept of sustainable development, the development process is expected to meet the present life needs without jeopardizing the needs of future generations in harnessing the potentials of natural resources efficiently and effectively. Lynch (2011) took the meaning of sustainable development from the World Commission on Economic Development (WCED) in 1987 i.e. "Defined as development that meets the needs of the present without compromising the ability of future generations to meet their own needs". Sustainable development requires simultaneous adaptation of the principles of environment, economy and equity. Azapagic (2003) formulated the concept of Corporate Sustainability Management System (CSMS) into five stages, namely, policy development, planning, implementation, communication, evaluation, and improvement. The five stages will be formulated to address the three issues, indicators and units of economic contribution, environmental performance and social responsibility. According to Immawan et al. (2015), sustainability has become the main keyword both in the business world today and in the wider aspect i.e. the community. Application of sustainability system must meet three aspects, namely, sustainable environment, economy and social. This system is often applied at the corporate, government, agriculture, health, and others. 
The continuous production pattern helps companies to save money, improve competitiveness, and reduce the impacts of environment, health and safety.

Inside the company, the problems of efficiency and effectiveness of resource use, especially the cost of production are always in the spotlight for the users of financial statements. According to Marota et al. (2015), production cost is a major cost component in a manufacturing company, and companies should focus on resource efficiency to minimize production costs. According to Fakoya (2014), the debate on the efficiency of resources, especially with regard to the waste reduction and management is not only a concern for scientists and environmentalists but also for the company management.

The management has understood and known that the current conventional accounting system has a number of limitations. These limitations will appear especially when the accounting system is connected with business operations related to the environmental management. Costs related to the environment in general include costs of sewage treatment, waste disposal, construction of the installation, third parties, licensing fees, and so on.

In an effort to contribute to the problem of waste reduction from a different perspective, the contemporary accounting management develops a collection tool for the quantification of certain wastes, namely, Material Flow Cost Accounting (MFCA) to provide financial and non-financial information in order to support the decision of waste reduction by managers). MFCA is a key tool of management approach known as flow management that aims specifically to manage manufacturing processes related to material flow, energy, and data so that the manufacturing process can be more efficient and in accordance with the targets set (Hyrslova et al. 2011; Viere et al. 2011). MFCA is a management information system that explores all input materials that flow in the production process and measures the output in the finished product and waste (Kokubu and Kitada, 2009). Furthermore, Kokubu and Kitada (2009) explain that the MFCA method will explore in detail the physical flow of materials in the production process, from input, work in process to finished goods and calculates costs by multiplying and quantifying materials from the unit price. Schmidt and Nakajima (2013) shows the essential idea behind the MFCA. In the classical cost accounting, all costs will only be allocated to production as unit costs. They also point out that it will share the material costs into production costs and waste materials, depending on where the materials will end. In addition, the system costs that can be generated by the company based on storage, processing or transportation will be added. This system was developed because in the conventional cost accounting, transparency of information regarding the potentials for materials and energy flow, including support management decisions related to the increase in the use of materials and energy efficiency, is very limited. In this accounting, costs and material losses of energy are usually not counted, and because the material cost can be directly allocated to production cost, the cost will instantly cut the cost center in the cost of goods sold of the company so that the company management will immediately focus on reducing it. Furthermore, Hyrslova et al. (2011), Viere et al. (2011) and Ichimura (2012), categorize MFCA as a management tool showing the flow of materials with a focus on the importance of information to optimize the production process. The aims are to present the system at the output of finished goods and demonstrate the importance of the data obtained from the MFCA system for optimization of manufacturing processes. The advantage of using the concept of MFCA is that it is able to increase profits and productivity (internal) as well as to reduce the negative impacts to the environment (external), which further contribute to the development of enterprise sustainability (corporate sustainable development). The research by Elewa (2007) shows that the concept of development of the company sustainability has grown in recent decades, and it has become a center of attention for the sector and business world. Bare (2011) states that there are five elements within the organization in the development of sustainable environment i.e. economy sustainability, social indicators, environmental analysis, sustainability indicators selected independently, materials, and resources used.

Problems in PT XYZ exist in all sustainability dimensions of the corporate i.e in economy, social, environment and technology and start from the levels of efficiency and cost-effectiveness of production as well as production waste processing. Production of medical devices should refer to the "Guidelines for Management of Medical Devices" issued by the Directorate of Medical Support Services and Health of the Ministry of Health of the Republic of Indonesia. According to this guideline, the medical device manufacturer is responsible for processes as follows: assessment on health tool needs; research and development; prototype 
testing; production; packaging and labeling; supply data maintenance and documentation maintenance; and management of production waste and tool contamination process.

Based on this, PT XYZ should be able to develop the concept of sustainable and environmentally friendly industry and production. According to the Ministry of Industry, the definition of green industry, sustainable industry or the broader definition such as the Green Development or the Green Economy is often taken from diverse perspectives so that the current terminology can have broad dimensions. The concept of green industry is not only related to the development of environmentally friendly industry but also to the implementation of an integrated, holistic and efficient industrial system. Thoughts on the concept of green industry resulted in various studies, including in manufacturing in which it is known as a sustainable manufacturing system or sustainable manufacturing. NACFAM-USA defines sustainable manufacturing as "the creation of manufactured products that are nonpolluting, conserve energy and natural resources, as well as economical and safe for employees, communities and customers". In referrence to this, green industry is defined as "an industry where in its production process prioritizes efficiency and effectiveness of resource use in a sustainable manner so as to harmonize industrial development with preservation of the environment and give benefits the society".

Previous research on MFCA was conducted by Marota et al. (2015) who carried out their research to design and implement MFCA in palm oil CPO processing plants to determine the influences on the increase of sustainability of the company. The results showed significant influences between the application of MFCA and corporate sustainability. Fakoya (2014) also conducted research on MFCA by adopting and adjusting the MFCA framework in support of management decisions for waste reduction. The results showed that there are significant influences on technology usage and management accounting equipment in supporting the decision making process of the corporate management for waste reduction. Kourilova and Plevkova (2013) conducted a study on detection model of MFCA with environmental accounting. The study shows that MFCA can be used as a model to detect both production and business of a company.
The objectives of this study are to apply green concepts and MFCA to PT XYZ, analyze their influences on the dimensions of corporate sustainability, and formulate suggestions for the improvement of the company performance in improving its sustainability. These objectives show the position of this research which is different from the previous research. This research is expected to be useful for manufacturing companies in general to increase the company sustainability, especially in reducing the impacts of waste and use of materials and inefficient energy with the application of green concepts and MFCA and to become a reference in the development of environmental management accounting studies, MFCA and company sustainability. The scope of this research includes the production process, the details of the production costs, and production material flow as well as variables that will be observed and analyzed to increase corporate sustainability in terms of economy, social, environment and technology.

\section{METHODS}

The research was conducted in the company which produces medical equipment and hospital furniture and has a factory in Sukabumi West Java from January to March 2016. The research was conducted using a combination of qualitative and quantitative methods, observations, and in-depth interview approaches. Creswell (2010) as well as Tashakkori and Teddlie (2010) combine qualitative and quantitative approaches to rationalize the existing data. The data used in this study are primary data and secondary data. Primary data were collected through in-depth interviews and a questionnaire was distributed to the internal and external company management including experts who have joined the MFCA training and external auditors of PT XYZ as many as 30 respondents. Secondary data were obtained from the financial statement data of PT XYZ for the year period of 2011-2013, literature study, as well as related literature and journals from the internet. The financial statements data were processed and explained based on the study description variables. The sampling technique in order to obtain the information and continued was continued with expert survey from the respondents to get justification for the setting of the indicators and values (Persada et al. 2014). For the implementation of Green Concepts and MFCA, the descriptive analysis method was used using a mix method and based on the implementation steps of Green Concepts and MFCA at PT XYZ. Description of each variable is presented in Table 1. 
Table 1. Description of variables

\begin{tabular}{|c|c|c|c|c|}
\hline Variable & Dimensions & Measurement & Scale & Reference \\
\hline $\begin{array}{l}\text { Green Concepts and } \\
\text { MFCA }\end{array}$ & $\begin{array}{l}\text { 1. Production cost (X1) } \\
\text { 2. Area width of } \\
\text { Production Factory } \\
\text { (X2) } \\
\text { 3. Production Value (X3) } \\
\text { 4. Production Material } \\
\text { Flow (X4) } \\
\text { 5. Green Process (X5) } \\
\text { 6. Green Product (X6) }\end{array}$ & $\begin{array}{l}\text { Monetary unit } \\
\text { Area width unit } \\
\text { Production Unit } \\
\text { Material Unit } \\
\text { Production Process } \\
\text { Production Quality }\end{array}$ & Interval & Marota et al. (2015) \\
\hline \multirow[t]{4}{*}{$\begin{array}{l}\text { Company } \\
\text { Sustainability }\end{array}$} & Economy & $\begin{array}{l}\text { Sales, net income, and } \\
\text { investment }\end{array}$ & Interval & Azapagic (2003) \\
\hline & Environment & $\begin{array}{l}\text { Costs of waste treatment } \\
\mathrm{K} 3 \text {, and other utility } \\
\text { costs }\end{array}$ & Interval & Azapagic (2003) \\
\hline & Social & $\begin{array}{l}\text { Costs of salaries, } \\
\text { benefits and post- } \\
\text { retirement benefits } \\
\text { (pension) }\end{array}$ & Interval & Azapagic (2003) \\
\hline & Technology & $\begin{array}{l}\text { Costs of supplies, } \\
\text { research and } \\
\text { development }\end{array}$ & Interval & Azapagic (2003) \\
\hline
\end{tabular}

To measure the influence of green concepts and MFCA on the dimensions of corporate sustainability, the multiple regression analysis was used to answer the following research hypotheses:

$\mathrm{H} 0$ : there are simultaneously significant effect of green concepts and MFCA variables which are represented by the attributes of the production costs (X1), production factory area width (X2), production value (X3), production material flow (X4), as well as the application of the concepts of green process (X5) and green product (X6) on the dimensions of corporate sustainability.

H1: there are no simultaneously significant effects of the variables of Green Concepts and MFCA which are represented by attributes of production costs (X1), production factory area width (X2), production value $(\mathrm{X} 3)$, production material flow of (X4), and application of the concepts of green process (X5) and green product (X6) on the dimensions of corporate sustainability.
According to Sugiyono (2014), multiple regression analysis is used to predict the rise and fall of the dependent variables, when two or more independent variables as predictor factors where values are manipulated or decreased or increased. In accordance with the description of the previous variables, there are 6 (six) independent variables in was this study. The model of multiple regression equation used to estimate the dimension values of the company sustainability that are influenced by the variables of green concepts and MFCA is as follows:

$$
\mathrm{Y}=\alpha+\beta_{1} \mathrm{X}_{1}+\beta_{2} \mathrm{X}_{2}+\beta_{3} \mathrm{X}_{3}+\beta_{4} \mathrm{X}_{4}+\beta_{5} \mathrm{X}_{5}+\beta_{6} \mathrm{X}_{6}
$$

The conceptual framework of this research is presented in a diagram of Figure 1. The existing phenomena and business facts that occurr in PT XYZ will underpin this study so that they can be analyzed to reduce their gap i.e. between the theories and important concepts and the green industry (green concepts) and MFCA, so that it can contribute to the creation of efficiency and effectiveness of production costs that support corporate sustainability. 
Issues and problems in the industry of PT XYZ

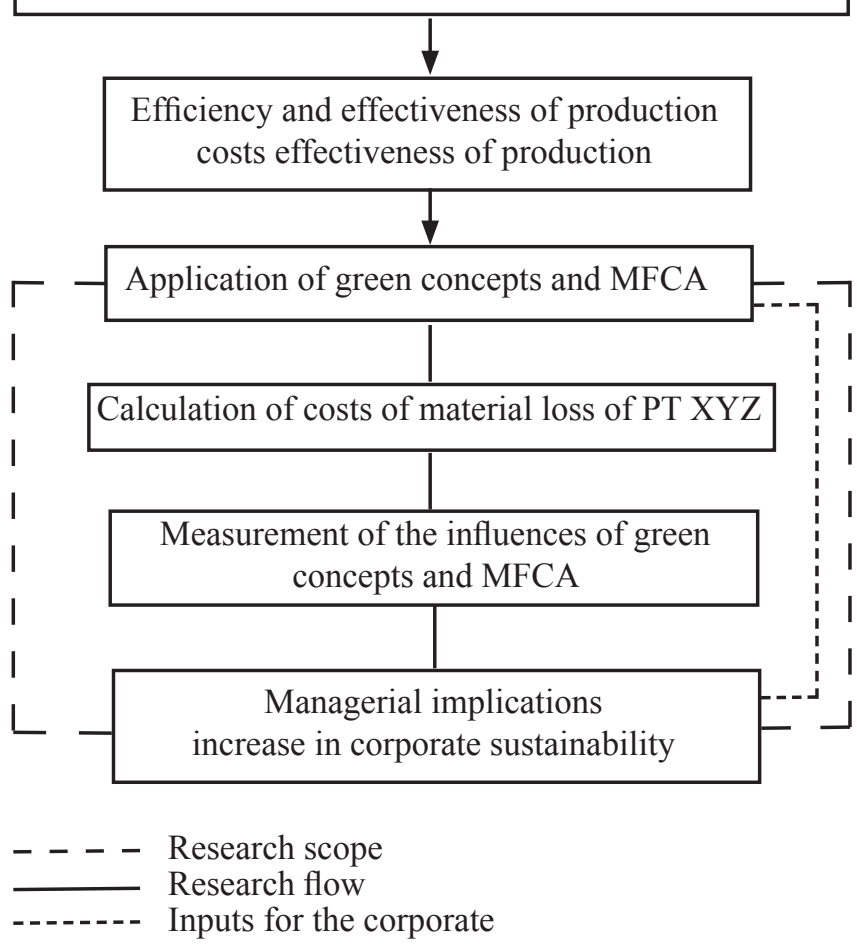

Figure 1. Research framework

\section{RESULT}

\section{Profile of PT XYZ}

PT XYZ is a manufacturing company of the medical equipment and hospital furniture that started from a domestic industry. This significant growth is due to the company's strategy to focus only on the production of hospital furniture. In 2003, PT XYZ obtained a full license issued by the Ministry of Health of Indonesia to produce hospital furniture, and in September 2003, the company obtained the quality management of ISO 9001:2000 with a certificate from TUV. The company also achieved ISO 13485 management system accreditation on June 8, 2007. The total area of the factory has increased from $200 \mathrm{~m}^{2}$ to $7,000 \mathrm{~m}^{2}$, with a total land area of $9,011 \mathrm{~m}^{2}$. The products produced by the company include operating tables, beds, and supporting equipment sold with the product brands of Karixa and SKN Medical. In 2009 and 2010, the products produced by the company were accepted in the domestic market and exported directly to the Middle East countries and indirectly sold to ASEAN countries. The company also sells its products to the World Health Organization (WHO), which then distributes the products to several countries in Asia and Africa.
From the secondary data of the financial statements of PT XYZ, the values corresponding to the existing dimension attributes from the period of 2011 to 2013 are presented in detail in Table 2

\section{Application of Green Concepts at PT XYZ}

PT XYZ has applied green concepts that include green strategy, green process, green products and green employee. Green strategy supports the business strategy which is always concerned about the aspects of protection and environmental development, safety and occupational health supported by the attitudes of commitment, involvement, and leadership. Green process helps manufacturing processes by using raw materials that are environmentally friendly or conserves energy and resources. Green product helps to create products which contain ingredients safe and environmentally friendly for humans and are efficient in their consumption of energy. Green employee will invite all members of the organization the company to have thoughts, attitudes, and environmentally friendly actions in their activities.

\section{MFCA Application}

The general procedure of MFCA consists of three steps, namely, the fee flow structure model, quantification of costs and performance evaluation costs (Schmidt et al. 2013). The design and implementation of MFCA begins with the identification of the centers of activity of MFCA (quantity center) consisting of seven stations, analysis of the allocation of material by weight and monetary as well as identification of the generated production waste as material loss costs. The production process at PT $\mathrm{XYZ}$ is sequential processing i.e. a processing pattern with a unit that passes from one process to another in a series arrangement. MFCA diagram can be seen in Figure 2.

The nature of the result of the application of MFCA is annual that is a recapitulation of the production costs spent within that year, in the form of costs of the production materials, energy for the electricity, water, and fuel, system for labor cost and waste treatment summarized in Table 3. PT XYZ suffered cost of material loss of Rp4.92 billion in 2013. Costs of energy, system and waste treatment are classified as costs of material losses which are potential for efficiency and effectiveness in production cost in the following period. 
Table 2. Details of Values of PT XYZ corresponding to dimensions of corporate sustainability

\begin{tabular}{lrrr}
\hline \multicolumn{1}{c}{ Dimensions } & \multicolumn{2}{c}{ Period } \\
\cline { 2 - 4 } & \multicolumn{1}{c}{2013} & \multicolumn{1}{c}{2011} \\
\hline Economy & & & \\
• Sale & $47,947,628,045$ & $59,023,016,733$ & $38,831,248,293$ \\
• Production Cost & $30,599,128,949$ & $40,953,351,805$ & $24,081,291,477$ \\
• Net Profit & $1,613,159,092$ & $2,727,467,923$ & $1,457,083,164$ \\
• Investment & $2,222,357,876$ & $2,351,288,977$ & $\mathrm{~N} / \mathrm{A}$ \\
Social & & & \\
• Salary & $3,479,404,563$ & $2,935,119,731$ & $2,454,200,854$ \\
- Allowance expense & $235,693,637$ & $217,730,052$ & $134,379,803$ \\
Environment & & & \\
• Waste processing & $17,412,244$ & $38,201,103$ & $\mathrm{~N} / \mathrm{A}$ \\
• K3 & $11,295,000$ & $12,843,600$ & $753,548,566$ \\
Technology & & & \\
• Supply cost & $79,469,309$ & $79,154,041$ & $47,200,000$ \\
• Research \& Development Cost & $9,844,200$ & $\mathrm{~N} / \mathrm{A}$ & $51,220,314$ \\
\hline
\end{tabular}

Source: Financial Report Data of PT XYZ for the period of $2011-2013$

Table 3. Recapitulation of results of MFCA application

\begin{tabular}{|c|c|c|c|c|c|}
\hline Cost & Material (Rp) & Energy (Rp) & System (Rp) & Waste processing $(\mathrm{Rp})$ & Total (Rp) \\
\hline Product & $25,709,143,991$ & - & - & - & $25,709,143,991$ \\
\hline Loss & - & $230,289,035$ & $4,659,695,923$ & $30,242,275$ & $4,920,227,233$ \\
\hline Total & $25,709,143,991$ & $230,289,035$ & $4,659,695,923$ & $30,242,275$ & $30,629,371,224$ \\
\hline
\end{tabular}

Source: Processed data of financial report of PT XYZ year 2013

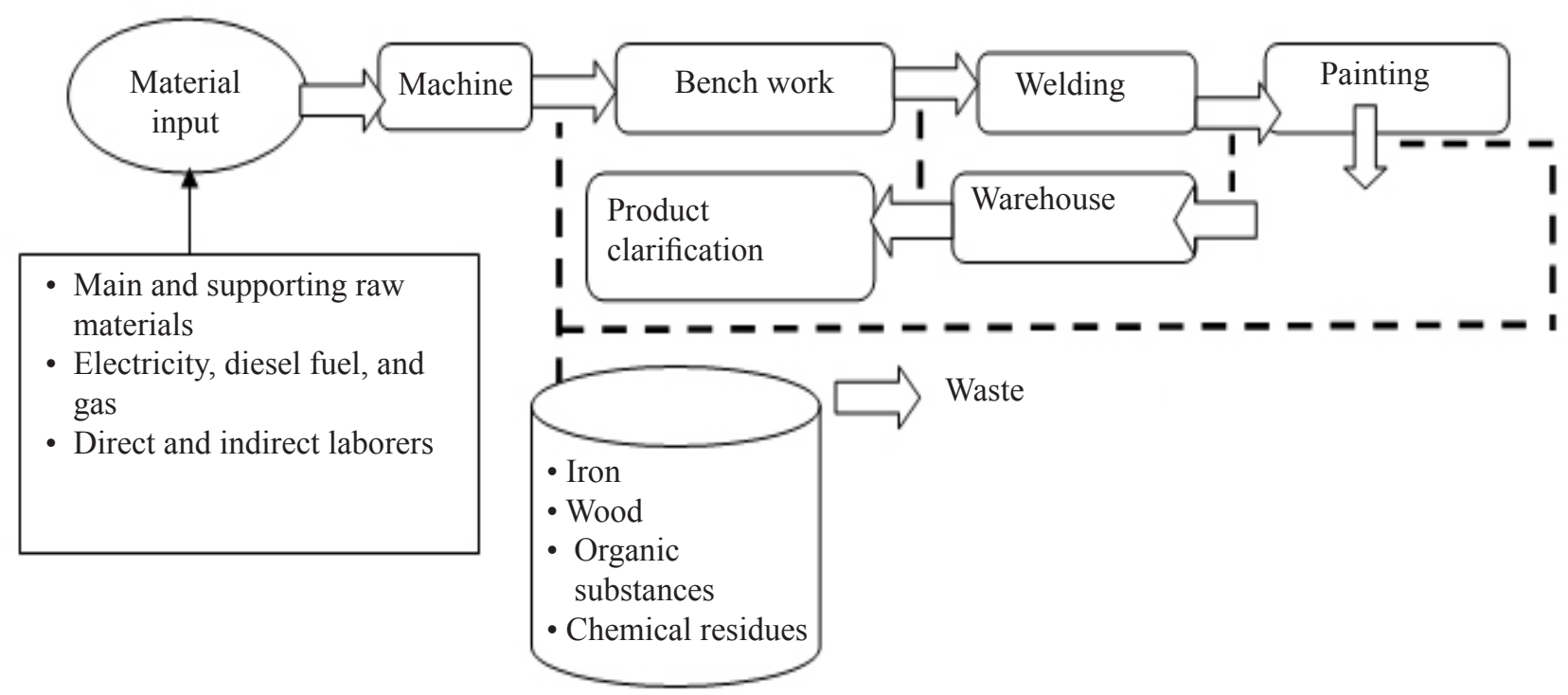

Figure 2. MFCA Diagram of PT XYZ

\section{Measurement of theInfluences of Green Concepts and MFCA on the Dimensions of Sustainability XYZ}

Measurement of the influences of green concepts and MFCA on dimensions of sustainability of PT XYZ was carried out by multiple regression analysis with a confidence level of $95 \%$. The complete results of the measurement of the influences are as follows:
Correlation Coefficient (R) and determinants (Adjusted R Square)

The results of correlation and determination are presented in Table 4. From the output of the model summary above, it can be seen that the $\mathrm{R}$ value (correlation coefficient) is 0.753 , indicating that the variables of company sustainability and those of green concepts and MFCA have a highly strong correlation. 
Table 4 shows the values of Adjusted R Square of 0.454 or $45.4 \%$, indicating that all variables of green concepts and MFCA are influential by $45.4 \%$ on the company sustainability variables, while the remaining $54.6 \%$ is influenced by other variables or factors beyond the research.

Table 4. Measurement of correlation and determinants

\begin{tabular}{ccccc}
\hline Model & R & R Square & $\begin{array}{c}\text { Adjusted } \\
\text { R Square }\end{array}$ & $\begin{array}{c}\text { Std. Error } \\
\text { of the } \\
\text { Estimate }\end{array}$ \\
\hline 1 & $.753^{\mathrm{a}}$ & .567 & .454 & .34453 \\
\hline a. Predictors: (Constant), $\mathrm{X}_{6}, \mathrm{X}_{4}, \mathrm{X}_{1}, \mathrm{X}_{5}, \mathrm{X}_{2}, \mathrm{X}_{3}$ & \\
F Test
\end{tabular}

The results of $\mathrm{F}$ test from the study variables are presented in Table 5. From the $\mathrm{F}$ value counted $>$ Ftable (5.013> 2.528) and Sig. $>0.05(0.142>0.002)$, it can be said that $\mathrm{H} 0$ hypothesis is accepted; therefore, the green concepts and MFCA variables significantly influence the company sustainability variables.

Table 5. Measurement of F Test

\begin{tabular}{llccccc}
\hline \multirow{2}{*}{ Model } & $\begin{array}{c}\text { Sum of } \\
\text { Squares }\end{array}$ & df & $\begin{array}{c}\text { Mean } \\
\text { Square }\end{array}$ & F & Sig. \\
\hline 1 & Regression & 3.570 & 6 & .595 & 5.013 & $.002^{\mathrm{b}}$ \\
& Residual & 2.730 & 23 & .119 & & \\
& Total & 6.300 & 29 & & & \\
& & & & & &
\end{tabular}

a. Dependent Variable: Y

b. Predictors: (Constant), $\mathrm{X}_{6}, \mathrm{X}_{4}, \mathrm{X}_{1}, \mathrm{X}_{5}, \mathrm{X}_{2}, \mathrm{X}_{3}$

\section{t Test}

The results of the $t$ test from the study variables are width presented in Table 6 . The dimension of the production cost has a significance value of $>0.05$ (0.095> 0.05), indicating that it has no significant influence on the corporate sustainability variables. The factory area dimension has a significance value of $>$ $0.05(0.364>0.05)$, so it does not significantly affect the company sustainability variables. The production value dimension has a significance value of $>0.05$ $(0.755>0.05)$, so it does not significantly affect the company sustainability variables either. Moreover, the production material dimension has a significance value of $>0.05(0.471>0.05)$, so it does not significantly influence the company sustainability. The dimension of green process has a significance value of $>0.05(0.078>$ 0.05 ), so it does not significantly influence the company sustainability. However, the green product dimension has a significance value of $<0.05(0.005<0.05)$, thus significantly influencing the company sustainability.

The result of the $t$ test shows that each dimension of the variables of green concepts and MFCA cannot affect the variables of company sustainability individually with a significant influence, indicating that PT XYZ should focus on continuous improvement toward the application of green concepts and MFCA as a whole and simultaneously on any attribute they represent.

\section{Managerial Implications}

Before the results of the research are concluded, managerial implications for the formulation of the performance of the production process will be formulated. The formulation of the production performance of PT XYZ, according to Saftiana et al. (2007), should be narrowed to the efficiency and effectiveness of production cost with a focus on valueadded activities and the cycle time and manufacturing cycle effectiveness (MCE). According to Marota et al. (2015), performance and efficiency can be enhanced through the concept of MFCA and MCE with improvement activities aimed at achieving cost effectiveness, lowering production costs and material losses, and improving environmental performance with the reprocessing of waste production in the form of management activity in any production quantity center. PT XYZ can apply the management concept of competitive cost to manage the activities of factories that provide added value (value added activities) and minimize the time for non-value added activities.

With a focus on high efficiency and low cost, the company is expected to compete with other competitors and fulfill the standard compliant of the products from distributors/Hospitals and the Ministry of Health and importers and to maintain the increase in the value of corporate sustainability in order to maximize profits earned and to provide safety to invest for shareholders as shareholder values. 
Table 6. Measurement of t Test

\begin{tabular}{|c|c|c|c|c|c|c|}
\hline & \multirow{2}{*}{ Model } & \multicolumn{2}{|c|}{ Unstandardized coefficients } & \multirow{2}{*}{$\begin{array}{c}\text { Standardized coefficients } \\
\text { Beta }\end{array}$} & \multirow{2}{*}{$\mathrm{t}$} & \multirow{2}{*}{ Sig. } \\
\hline & & B & Std. Error & & & \\
\hline \multirow[t]{7}{*}{1} & (Constant) & .587 & .801 & & .732 & .471 \\
\hline & $\mathrm{X} 1$ & .130 & .075 & .299 & 1.743 & .095 \\
\hline & $\mathrm{X} 2$ & -.128 & .138 & -.172 & -.926 & .364 \\
\hline & $\mathrm{X} 3$ & .067 & .213 & .079 & .316 & .755 \\
\hline & $\mathrm{X} 4$ & .121 & .165 & .176 & .733 & .471 \\
\hline & $\mathrm{X} 5$ & .281 & .152 & .289 & 1.844 & .078 \\
\hline & X6 & .334 & .108 & .500 & 3.095 & .005 \\
\hline
\end{tabular}

a. Dependent Variable: $\mathrm{Y}$

\section{CONCLUSIONS AND RECOMMENDATIONS}

\section{Conclusions}

Application of green concepts and MFCA in PT $\mathrm{XYZ}$ can have significant influences on the company sustainability dimensions as can be seen from the results of multiple regression analysis that has been conducted. Green concepts focus on the application process and the production of environmentally friendly production while MFCA focuses on the amount of material loss costs and generated production waste. Expected corporate sustainability is a continuous improvement of the entire production process and product quality in terms of the economic, social, environmental and technological dimensions.

The previous study on MFCA conducted by Marota et al. (2015) shows that there are significant influences of design and implementation of MFCA on the increase of the company sustainability. Compared with the result of this study, there is a link that MFCA provides potentials for information transparancy on the flow of materials and energy, including supports for the decision making of the management related to the increase of efficiency in the use of materials, energy, labor and waste treatment. MFCA will support and strengthen the application of green concepts in PT XYZ.

\section{Recommendations}

A number of suggestions given from the results of analysis conducted on the factory activities of PT $\mathrm{XYZ}$ include the application of MFCA to support the implementation of green concept and the management activities at each production quantity center. The corporate can also apply a competitive cost management concept to manage the value added activities and minimize the time for non-value added activities. Furthermore, the company should apply the calculation of job order cost and activity-based cost to the transparency of the production costs of each type of health appliance and furniture produced by PT $\mathrm{XYZ}$, and it should not be based on the process cost to determine the production considering the fact that production does not produce mass product for one type of product. To improve the performance of production in order to reduce time and activity of inspection or supervision for the procurement of material, the company can implement ERP: Enterprise Resource Planning as a computerized technology that supports information management system to manage and monitor the process of procurement of materials for production inputs (Brazel and Dang, 2008).

A number of suggestions given for further research include the modification of MFCA variable by calculating the production cost before and after the application of MFCA, including budget and production cost realization; comparison of the application of MFCA in 2 or 3 companies that have the same level of production capacity; and addition of each attribute for each dimension of corporate sustainability such as customer satisfaction, responsiveness and control of the management and standard operating procedures for waste processing.

\section{REFERENCES}

Azapagic A. 2003. Systems approach to corporate sustainability: a general management framework. Trans IChemE Journal 81 (B): 303-316.

Bare JC. 2011. Five key elements for environmental sustainable progress. International Journal for Sustainable Innovations 1(1): 91-98.

Brazel JF, Dang L. 2008. The effect of ERP system implementations on the management of earnings. Information System Journal 22 (2): 1-21. https:// doi.org/10.2308/jis.2008.22.2.1. 
Creswell JW. 2010. Research Design, Pendekatan Kualitatif, Kuantitatif, dan Mixed. Yogyakarta: Pustaka Pelajar Yogyakarta.

Elewa MM. 2007. The impact of enviromental accounting on the profit growth, development \& sustainability of the organization: a case study on Nypro Inc [tesis]. Massachusetts: University of Massachusetts Lowell

Fakoya MB. 2014. An adjusted material flow cost accounting framework for process wastereduction decisions in the South African brewery industry [Disertasi]. Pretoria: University of South Africa.

Hyrslova J, Vagner M, Palasek J. 2011. Material flow cost accounting (MFCA) - tool for the opti $\neg$ mization of corporate production processes. Business, Management and Education Journal 9(1): 5-18. https://doi.org/10.3846/bme.2011.01.

Ichimura H. 2012. Effect of the Introduction of Material Flow Cost Accounting on Enviromental Management. Paper on 2012 JSPS Asian CORE Program.

Immawan T, Marimin, Arkeman Y, Maulana A. 2015. Sustainable supply chain management for Make To Stock-Make To Order production typology case study: batik industry in Solo Indonesia. European Journal of Business and Management 7(11): 94-106.

[Kementerian Perindustrian] 2012. Pendalaman Struktur Industri melalui Efisiensi dan Efektivitas dalam Implementasi Industri Hijau. Jakarta: Kementerian Perindustrian.

Kokubu K, Kitada H. 2009. Conflicts and Solutions Between Material Flow Cost Accounting and Conventional Management Thinking. Paper on 6th Asia-Pacific Interdisciplinary Perspectives on Accounting Research (APIRA) Conference at University of Sydney on 12-13 July 2010.

Kourilova J, Plevkova D. 2013. DMFCA model as a possible way to detect creative accounting and accounting fraud in an enterprise. Financial Asset and Investing Journal 2(2): 14-27. https://
doi.org/10.5817/FAI2013-2-2.

Lynch KD. 2011. Measuring corporate sustainability performance: influences and issues to consider in metric conceptualization [disertasi]. Benedictine University.

Marota R, Marimin, Sasongko H. 2015. Perancangan dan Penerapan MFCA untuk Peningkatan Keberlanjutan Perusahaan PT XYZ. Jurnal Manajemen dan Agribisnis 12(2): 92-105.

Persada C, Sitorus SRP, Marimin, Djakapermana RD. 2014.Penentuanstatuskeberlanjutaninfrastruktur perkotaan (studi kasus: kota Bandarlampung). Jurnal Sosek Pekerjaan Umum 6(1): 17-27.

Saftiana Y., Ermadiana, Andriyanto RW. 2007. Analisis manufacturing cycle effectiveness dalam meningkatkan cost effectiveness pada pabrik pengolahan kelapa sawit. Jurnal Akuntansi dan Keuangan 12(1): 106-121.

Schmidt A, Hache B, Herold F, Götze U. 2013. Material flow cost accounting with umberto ${ }^{\circledR}$. Paper on Workshop of the cross-sectional group 1 "Energy related technologic and economic evaluation" of the Cluster of Excellence eniPROD, WissenschaftlicheScripten,Auerbach, Germany.

Schmidt M, Nakajima M. 2013. Material flow cost accounting as an approach to improve resource efficiency in manufacturing companies. International Journal 2(2): 358-369. https://doi. org/10.3390/resources2030358.

Sugiyono. 2014. Metode Penelitian Bisnis (Pendekatan Kuantitatif, Kualitatif, dan R\&D). Bandung: CV Alfabeta Bandung.

Tashakkori A, Teddlie C. 2010. Mixed Methodology Mengombinasikan Pendekatan Kualitatif dan Kuantitatif. Yogyakarta: Pustaka Pelajar Yogyakarta.

Viere T, Möllerand A, Prox M. 2011. Material flow cost accounting approach to improvement assessment in LCA. International Journal for Sustainable Innovations 1(1): 1-7. 